\title{
Corpus
}

Entre A. Dumas et J. Potocki : retour sur des phénomènes $d$ 'allophonie vocalique dans les parlers poitevins nord-ouest ou le transcrupscrit retrouvé dans une cabane à huîtres Jean-Léo Léonard

\section{(Q) OpenEdition Journals}

Édition électronique

URL : http://journals.openedition.org/corpus/276

DOI : $10.4000 /$ corpus. 276

ISSN : $1765-3126$

\section{Éditeur}

Bases; corpus et langage - UMR 6039

\section{Édition imprimée}

Date de publication : 1 décembre 2004

ISSN : 1638-9808

\section{Référence électronique}

Jean-Léo Léonard, «Entre A. Dumas et J. Potocki : retour sur des phénomènes d'allophonie vocalique dans les parlers poitevins nord-ouest ou le transcrupscrit retrouvé dans une cabane à huîtres », Corpus [En ligne], 3 | 2004, mis en ligne le 02 décembre 2005, consulté le 08 septembre 2020. URL : http://journals.openedition.org/corpus/276 ; DOI : https://doi.org/10.4000/corpus.276

Ce document a été généré automatiquement le 8 septembre 2020.

(c) Tous droits réservés 


\title{
Entre A. Dumas et J. Potocki : retour sur des phénomènes d'allophonie vocalique dans les parlers poitevins nord-ouest oul etranscrupscrit retrouvé dans une cabanea à huitres
}

\author{
Jean-Léo Léonard
}

\section{NOTES}

*. Ce titre est un résumé allusif au sujet des conditions de réalisation de cette contribution à ce numéro de Corpus qui traite des affres de la constitution de corpus phonologiques. Une allusion à deux figures littéraires connues (Alexandre Dumas pour son Vingt ans après et Jan Potocki pour Le manuscrit trouvé à Saragosse), sans préjuger pour autant d'une adhésion de l'auteur de ces lignes aux idées de ces deux classiques. L'allusion tient en ce que je traite ici de données recueillies il y a vingt ans (comme les trois mousquetaires dans vingt ans après ...) dans l'île de Noirmoutier et le Marais nord vendéen, en me basant sur des transcriptions phonétiques de phonogrammes d'une durée moyenne de quinze minutes de parole spontanée, que je n'avais pas eu l'occasion d'exploiter suffisamment lors de la rédaction de ma thèse de doctorat sur la variation dialectale du poitevin insulaire septentrional. C'est bien de ce dialecte, et non du français contemporain ou standard qu'il sera question ici, la langue étant alors couramment parlée par la plupart des adultes insulaires, mais plus par les enfants, dans les années 1980. Avec la très précieuse collaboration de Cédric Gendrot, Paris 3 et UMR $7018 \mathrm{du}$ CNRS, auteur de plusieurs scripts pour Praat qui ont permis de mener à bien 
cette recherche. Les éventuelles erreurs d'analyse ou de jugement sont entièrement de la responsabilité de JLL.

\section{RÉSUMÉS}

Les parlers poitevins nord-occidentaux (Noirmoutier, Marais nord vendéen) présentent une variation allophonique complexe du vocalisme. On peut distinguer plusieurs niveaux de diphtongaison qui rendent ces variétés particulièrement intéressantes pour l'analyse phonologique. L'étonnante diversité des formes phonétiques en surface peut cependant se réduire à deux grandes catégories de noyaux vocaliques, simples (monophtongues) et complexes (monophtongues longues et diphtongues sous-jacentes). Les premières sont sujettes à des contraintes d'expression liées à l'atérité, ou laxité, tandis que les deuxièmes alternent des voyelles tendues avec des diphtongues décroissantes ou fermantes dans l'oral spontané. Cette contribution $^{*}$ traite principalement de comment une enquête sur la structure phonologique d'une variété dialectale peut durer vingt ans, en faisant alterner diverses approches et divers angles de vue sur les données: transcription phonétique, spectrographie acoustique, analyse phonologique tendant à devenir une enquête phonologique amenée à remettre en cause ses prémisses et ses instruments d'observation des faits de parole pour aboutir à une description de la langue.

From A.Dumas to J. Potocki : revisiting phonetic variation of North-Western Poitevin vowels 20 years later

Poitevin, a Gallo-Roman dialect spoken in the French mid-west, shows intricate patterns of phonetic variation of vowels. Several layers of diphthongization make the north-western subdialect particularly interesting for anyone interested in tracing phonemic patterns on the grounds of complex outputs. Puzzling data can nevertheless be analysed as, on the one hand, a main layer of four simple basic categories of complex syllabic nuclei, amounting to a handful of long monophthongs and diphthongs, and short vowels in input which are spelled out according to A.T.R. constraints in casual speech, resulting in additional layers of surface diphthongization on the other hand. The discovery of phonemic patterns on the grounds of phonetic diversity may be achieved either through phonetic transcription and acoustic analysis, or through phonological inquiry. The comparison of these two methods is the focus of the research that is presented here, which in fact was carried out over the past 20 years. The paper inquires on how complex phonological data can be handled with the help of various analytical devices, including phonetic software and conflicting theories of the internal structure of syllabic nuclei.

\section{INDEX}

Mots-clés : corpus, phonologie, phonétique, prosodie, accent, voyelles, diphtongues, dialectes d'Oïl, Praat, traitement des données, Noirmoutier 
AUTEUR

JEAN-LÉO LÉONARD

UMR 7018, Université Paris 3 